geography of the coasts of Brazil and west Africa, the equatorial zone of the Atlantic is the narrowest part today and overlap of the coasts in early Tertiary times would have greatly narrowed the sea crossing. The Ceará and Sierra Leone rises are equatorial, as is the Vema transform sliver, which is currently 600 metres below sea-level and is capped by Miocene reef limestones similar to those of the Bahamas ${ }^{6}$. Prevailing ocean currents would further have favoured drifting from Africa towards central South America. The history of the Caribbean region involves two volcanic chains between Central and South America that were active at various times during the Tertiary, and a major obstacle to southerly islandhopping would have been the strong eastwest ocean currents between the Pacific and the Atlantic.

Because of the lack of isotopic dating for the Mustersan, there is still a gap of unknown length (probably between 5 and $15 \mathrm{Myr}$ ) in our knowledge of mammal faunal sequences in South America. It was during this time that the rodents, and perhaps also the primates, reached the continent.

Bob Savage is in the Department of Geology, University of Bristol, Wills Memorial Building, Queens Road, Bristol BS8 1RJ, UK.

1. Wyss, A. R. et al. Nature 365, 434-437 (1993)

2. Hoffstetter, R. C. r. hebd. Séanc. Acad. Sci., Paris D269, 434-437 (1969).

3. MacFadden, B. J. J. hum. Evol. 19, 7-21 (1990).

4. Ciochon, R. L. \& Chiarelli, A. B. in Evolutionary Biology of the New World Monkeys and Continental Drift (eds Ciochon, R. L. \& Chiarelli, A. B.) 459-501 (Plenum, New York, 1980)

5. McKenna, M. C. in Evolutionary Biology of the New World Monkeys and Continental Drift (eds Ciochon, R. L. \& Chiarelli, A. B.) 43-77 (Plenum, New York, 1980). Chiarelli, A. B.) 43-77 (Plenum, New York, 1980).
Bonatti, E. \& Crane, K. Sci. Am. 250, 34-47 (1984).

7. Tarling, D. H. in Evolutionary Biology of the New World Monkeys and Continental Drift (eds Ciochon, R. L. \& Chiarelli, A. B.) 1-41 (Plenum, New York, 1980).

\title{
The D4 and schizophrenia
}

\section{Leslie L. Iversen}

ONE of the achievements of research on mental illness in the past 20 years has been the recognition of the key role that brain dopamine systems play in mediating the actions of anti-schizophrenic drugs. The starting point was the observation that amphetamines, which can cause a schizophrenia-like psychosis in people, act by promoting the release of dopamine in the brain, and that anti-schizophrenic drugs (neuroleptics) potently block the psychostimulant actions of amphetamines in animals and humans ${ }^{1,2}$. The 'dopamine hypothesis' received further support when biochemical studies revealed directly that neuroleptic drugs act as antagonists at brain dopamine receptors of the D2 subtype ${ }^{3,4}$.

The paper by Seeman and colleagues on page 441 of this issue ${ }^{5}$ may represent a further advance, one that is potentially of high significance. The conclusions to be drawn from this work are that the functional coupling of dopamine receptors may be abnormal in the brains of schizophrenic patients, and that this phenomenon is accompanied by a selective increase in the density of a particular D2-related receptor subtype, the dopamine D4 receptor.

Several previous studies, involving use of various radioligands in samples of postmortem brain tissue, have examined the possibility that abnormally large numbers of dopamine D2 receptors might be present in the schizophrenic brain. Most such studies did indeed reveal increased density of D2 receptors. But the interpretation of the findings has remained controversial, as before they died most patients had been treated with neuroleptic drugs, which are themselves known to cause increases in dopamine receptors in animal brain on chronic administration ${ }^{6-8}$. Moreover, two studies in living patients, using positron emission tomography, gave conflicting results. Wong et al. ${ }^{9}$ found substantial increases in dopamine receptors in ten drug-naive patients, using $\left[{ }^{11} \mathrm{C}\right]$ spiperone as the radioligand. Farde et al. ${ }^{10}$, however, failed to find any such increases in 18 similar subjects, using $\left[{ }^{11}\right.$ C]raclopride.

The results reported by Seeman et al. may help to reconcile some of these differences. The authors sought to measure the density of dopamine receptors of the D4 subtype, which is of particular interest because it is a possible target for the atypical anti-schizophrenic drug clozapine ${ }^{11}$. In the absence of a radioligand with selectivity for D4 sites, they employed $\left[{ }^{3} \mathrm{H}\right]$ raclopride, which has high affinity for dopamine D2 and D3 receptors but not for $\mathrm{D} 4$, and $\left[{ }^{3} \mathrm{H}\right]$ emonapride or $\left[{ }^{3} \mathrm{H}\right]$ spiperone, which bind D2, D3 and $\mathrm{D} 4$ sites with high affinity. The number of D4 sites is calculated as the difference between $\left[{ }^{3} \mathrm{H}\right]$ raclopride and $\left[{ }^{3} \mathrm{H}\right] \mathrm{em}$ onapride binding ${ }^{12}$. According to this approach, D4 receptors represent a relatively minor proportion of the total dopamine receptor population in basal ganglia tissue from normal subjects, or from patients dying with Parkinson's or Alzheimer's disease. In samples from 32 patients who had been diagnosed as schizophrenic, however, there was a sixfold increase in D4 receptor numbers, which in these cases represented up to 40 per cent of the total D2-like population.

In addition, Seeman and co-workers found that tissue from schizophrenic patients differed from that of control subjects, and from that of Huntington's or Parkinson's patients, in being unresponsive to guanine nucleotides. Guanine nucleotides normally cause an increase in $\left[{ }^{3} \mathrm{H}\right]$ raclopride binding, but the effect was not evident in the schizophrenia tissue samples. This observation suggests that there may be some alteration in the Gprotein-mediated functional coupling of dopamine receptors in schizophrenia, which could be as important as the change in $\mathrm{D} 4$ receptor numbers.

The vexed question of whether these changes are inherent to the psychotic illness, or are merely the effects of chronic treatment with neuroleptic drugs, is addressed in two ways. The authors show data from 'drug-free' patients (six out of a total of 32 in the schizophrenia group), who exhibited similar changes. And they compare their results with data from patients dying with Alzheimer's or Huntington's disease, most of whom were treated in life with doses of neuroleptics similar to those used in the schizophrenia group, but failed to show any biochemical changes.

The history of biological research in schizophrenia is littered with the skeletons of once attractive hypotheses, and it will be essential to see whether the conclusions of Seeman and colleagues can be confirmed in other laboratories. Counting receptor numbers by estimating the difference between two large numbers is far from ideal, but the possible proliferation of dopamine D4 receptors in the brains of schizophrenic patients should be directly verifiable when selective dopamine D4 radioligands are developed. If the findings can be confirmed, the present paper will be a landmark on the way to a genuine improvement in our understanding of this enigmatic illness.

Leslie L. Iversen is at Merck, Sharp and Dohme Research Laboratories, Neuroscience Research Centre, Terlings Park, Eastwick Road, Harlow, Essex CM2O 2QR, UK.

1. Randrup, A. \& Munkvad, P. Psychopharmacologia 7, 416-422 (1965)

2. Snyder, S. H., Banarjee, S. P. \& Yamamura, H. T. Science 184, 1243-1253 (1974).

3. Creese, I.. Burt, D. R. \& Snyder, S. H. Science 192, 481-483(1975).

4. Seeman, P. et al. Nature 261, 717-719 (1976)

5. Seeman, P., Guan, H. C. \& Van Tol, H. H. M. Nature 365, 441-445 (1993).

6. Cross, A. J., Crow, T. J. \& Owen, F. Psychopharmacologia 74, 122-124 (1981)

7. Mackay, A. V.T., Iversen, L. L. \& Rossor, M. Arch. gen. Psychiatry 39, 991-997 (1982).

8. Seeman, P. etal. Neuropsychopharmacology 1, 5-15 (1987).

9. Wong, D. F. et al. Science 234, 1558-1563 (1986).

10. Farde, L. et al. Arch. gen. Psychiatry 44,671 (1987).

11. Iversen, L. L. Nature 358, 109 (1992).

12. Seeman, P. etal. Synapse 14, 247-253 (1993). 